http://zoobank.org/urn:lsid:zoobank.org:pub:C9A1CFCB-D534-4398-B1F3-10F774F2880B

\title{
A NEW SPECIES OF MICROHYLA (ANURA: MICROHYLIDAE) FROM SUMATRA, INDONESIA
}

\author{
Vestidhia Y. Atmaja ${ }^{* 1}$, Amir Hamidy ${ }^{2}$, Tuty Arisuryanti ${ }^{1}$, \\ Masafumi Matsui ${ }^{3}$ and Eric N. Smith ${ }^{4}$ \\ ${ }^{1}$ Graduate Program, Faculty of Biology, Universitas Gadjah Mada, \\ Jl. Teknika Selatan, Sleman, Yogyakarta, Indonesia \\ ${ }^{2}$ Zoology Division (Museum Zoologicum Bogoriense), Research Centre for Biology, \\ Indonesian Institute of Sciences, Gd. Widyasatwaloka, Jl. Raya Jakarta-Bogor Km 46, \\ Cibinong, West Java, Indonesia \\ ${ }^{3}$ Graduate School of Human and Environmental Studies, Kyoto University, \\ Yoshida Nihonmatsu-cho, Sakyo-ku, Kyoto 606-8501, Japan \\ ${ }^{4}$ Amphibian and Reptile Diversity Research Center and Department of Biology, \\ University of Texas at Arlington, 501 S Nedderman Drive, Arlington,TX 76010, USA \\ *Corresponding author: hamidyamir@gmail.com; vestidhia.atmaja@mail.ugm.ac.id
}

Received: 13 July 2018; Accepted: 17 December 2018

\begin{abstract}
A new species of frog in the genus Microhyla is described from Sumatra, Indonesia based on molecular and morphological characters. This new species was previously confused with M. achatina, a Javan endemic. This new species is diagnosable from its congeners by possessing a medium size (SVL in adult males $18.20-21.32 \mathrm{~mm}$, in adult females $20.37-25.51 \mathrm{~mm}$ ), a stout body, a nostrileyelid length being about half of the snout length, having a single outer palmar tubercle, a tibiotarsal articulation reaching the center of the eye (when the hindlimbs are stretched and adpressed to the body), having finger and toe tips dilated, having the dorsum with medial longitudinal grooves, and excibiting a very thin and short dark stripe on the temporal region above a wider cream stripe, extending from the postorbital area to insertion of forelimb. Additionally, the new species is characterized by possessing relatively little foot webbing. Uncorrected $16 \mathrm{~S}$ rRNA sequence divergences between the new taxon and sequences for other congeneric species available ranged from 4.8 to $15.0 \%$.
\end{abstract}

Keywords: cryptic species, mitochondrial DNA, phylogeny, taxonomy

\section{INTRODUCTION}

Narrow-mouthed Frogs of the genus Microhyla Tschudi, 1838 are widely distributed from the Ryukyu Islands (Japan) to the Indian Subcontinent, and including the intermediate regions of Indochina, the Sunda Shelf and Philippine islands (Matsui et al., 2005; Frost, 2017). The genus contains 41 species, six of them known to occur in Sumatra, M. achatina Tschudi, 1838; M. berdmorei (Blyth, 1856); M. fissipes Boulenger, 1884; M. heymonsi Vogt, 1911, M. palmipes Boulenger, 1897; and M. superciliaris Parker, 1928 (Parker, 1934; Frost, 2017; Pradana, 2017).

The type species of the genus is Microhyla achatina (Tschudi, 1838). The name $M$. achatina was previously applied to several populations from Myanmar; Peninsular Malaysia; Sumatra, Java, Bali, and the Philippines (van Kampen, 1923; McKay, 2006). Then, molecular studies proved that the populations outside of Indonesia belonged to other species (Matsui et al., 2011 \& 2013; Frost, 2017) and M. achatina was considered a Javanese endemic (Natus, 2005; Mckay, 2006). Matsui et al. (2011) firstly examined specimens from Sumatra that are morphogically look alike to M. achatina from Java, and these were suspected to be different 
from $M$. achatina, based on large genetic distances from the later (16S rRNA 5.5-6.6\%), and referred to it as Microhyla sp. 3. In this study, we add more sample sized and analyze the taxonomic status of $M$. achatina Sumatra based on molecular and morphological data and describe it as a new species.

\section{MATERIALS AND METHODS}

\section{Sampling design}

We examined a total of 29 partial sequences of the consecutive mitochondrial DNA genes $12 \mathrm{~S}$ and $16 \mathrm{~S}$ rRNA of Microhyla cf. achatina from Sumatra and members of the $M$. achatina group of Matsui et al. (2011), M. berdmorei, M. fissipes, M. heymonsi, $M$. achatina (from Gede Pangrango, West Java; Ungaran and Pekalongan, Central Java), Microhyla sp. 3, M. orientalis, M. mantheyi, M. borneensis, and M. malang, and six outgroups (four congeneric [M. butleri, M. palmipes, M. perparva, and M. superciliaris] and Kalophrynus pleurostigma and Oreophryne monticola; see Table 1). Specimens collected are presented in Fig. 1 and Table 1. Voucher specimens and tissues are stored in Museum Zoologicum Bogoriense (MZB), Research Center for Biology - Indonesian Institute of Sciences (LIPI), and at the Amphibian and Reptile Diversity Research Center (ARDRC), University of Texas at Arlington (UTA).

\section{Molecular analyses}

The methods for DNA extraction, amplification and sequencing for the $12 \mathrm{~S}$ and $16 \mathrm{~S}$ rRNA gene fragments are the same reported by Matsui et al. $(2011,2013)$. DNA sequences were edited using the ChromasPro software (Technelysium Pty Ltd., Tewantin, Queensland, Australia). All sequences, including those from Genbank (Table 1) were aligned using Clustal W in MEGA 7 (Kumar et al., 2016). Phylogenetic trees were constructed in Neighbour Joining (NJ), Maximum Likelihood (ML) and Bayesian Inference (BI) analyses. NJ analysis was conducted in MEGA 7 using p-distances and 1000 bootstrap replicates. Rate evolution models for ML and BI analyses were identified under the Akaike Information Criterion executed in Kakusan 4 (Tanabe, 2011). BI analysis was conducted in Mr. Bayes ver. 3.1.2 (Ronquist \& Huelsenbeck, 2003), with a general time-reversible (GTR) model of DNA evolution and a gamma shape parameter $(\mathrm{G})$. We ran the analysis for 6 million generations and sampled every 100 generations. The consensus tree was calculated after omitting the first $25 \%$ of the trees as burn-in. For ML analysis we used Treefinder ver. March 2011 (Jobb et al., 2004) with general time-reversible (GTR) and a gamma shape parameter (G). Tree nodes considered as strongly supported when having bootstrap values of $70 \%$ or more, for ML and NJ analyses (Hillis \& Bull, 1993). In BI analysis, nodes with BPPs higher than 95\% were considered statistically significant (Leaché \& Reeder, 2002). We also calculated genetic distances of 16S rRNA gene using uncorrected p-distances with MEGA 7. 


\section{Morphology analysis}

We examined specimens of Microhyla achatina stored in the Museum Zoologicum Bogoriense (MZB), Research Center for Biology-Indonesian Institute of Sciences (LIPI) and at the Amphibian and Reptile Diversity Research Center (ARDRC), University of Texas at Arlington (UTA) (Appendix 1). For comparisons, we also examined the type series of $M$. achatina (syntypes RMNH 1728) stored in the Naturalis Biodiversity Center (now merging the collections of the Rijksmuseum van Natuurlijke Historie, RMNH, and the Universiteit van Amsterdam, Zoologisch Museum, ZMA).

We measured 39 characters with a dial caliper to the nearest $0.01 \mathrm{~mm}$. The following characters were taken (sometimes modified) from Matsui (1984, 2013): (1) snout-vent length (SVL); (2) body width (BW), greatest width of body; (3) head length (HL), from tip of snout to hind border of angle of jaw (not measured parallel with the median line); (4) head width (HW); (5) head depth (HD); (6) snout length (SL); (7) eye length (EL); (8) nostril-eyelid length (N-EL); (9) head width (HW); (10) internarial distance (IND); (11) interorbital distance (IOD); (12) upper eyelid width (UEW); (13) forelimb length (FLL); (14) lower arm and hand length (LAL), from elbow to tip of third finger; (15) first finger length (1FL), from distal end of inner palmar tubercle to tip; (16) hand length (HAL), from proximal end of outer palmar tubercle to tip of third finger; (17) inner palmar tubercle length (IPTL); (18) outer palmar tubercle length (OPTL); (19) hindlimb length (HLL); (20) tibia length (TL); (21) foot length (FL); (22) inner metatarsal tubercle length (IMTL); (23) first toe length (1TOEL), from distal end of inner metatarsal tubercle to tip of first toe; (24) outer metatarsal tubercle length (OMTL); (25) first finger width (1FW), measured at the distal phalanx; (26-28) finger disk diameters (2-4FDW); (29-33) toe disk diameters (1-5 TDW); and (34-39) finger lengths (13 FLO, 2-4 FLI), for outer surface (O) of the first, inner side (I) of the fourth, and both sides of the remaining fingers, measured from tip to the junction of the neighboring finger.

In addition to morphometric analyses, we examined and scored several qualitative characters: snout shape, finger and toe tip shape, median longitudial groove dorsally on finger and toe tips, ventral color, lateral and dorsal body color, anal region color, temporal/ postorbital region and vertebral stripes, and dark stripe pattern of hind legs. We compared morphological data among populations of $M$. achatina from Java and Sumatra using a multivariate Principal Component Analysis log 10 transformed values (Thorpe, 1975). In univariate analysis we used converted morphometric characters (ratio to SVL; R), checked the distribution data and compared using T-Test Independent analysis. Both analyses were conducted using IBM SPSS Statistic 22 (IBM corp., 2013). We followed Savage \& Heyer (1967) as modified by Myers and Duellman (1982) for the description of toe-webbing formula. 


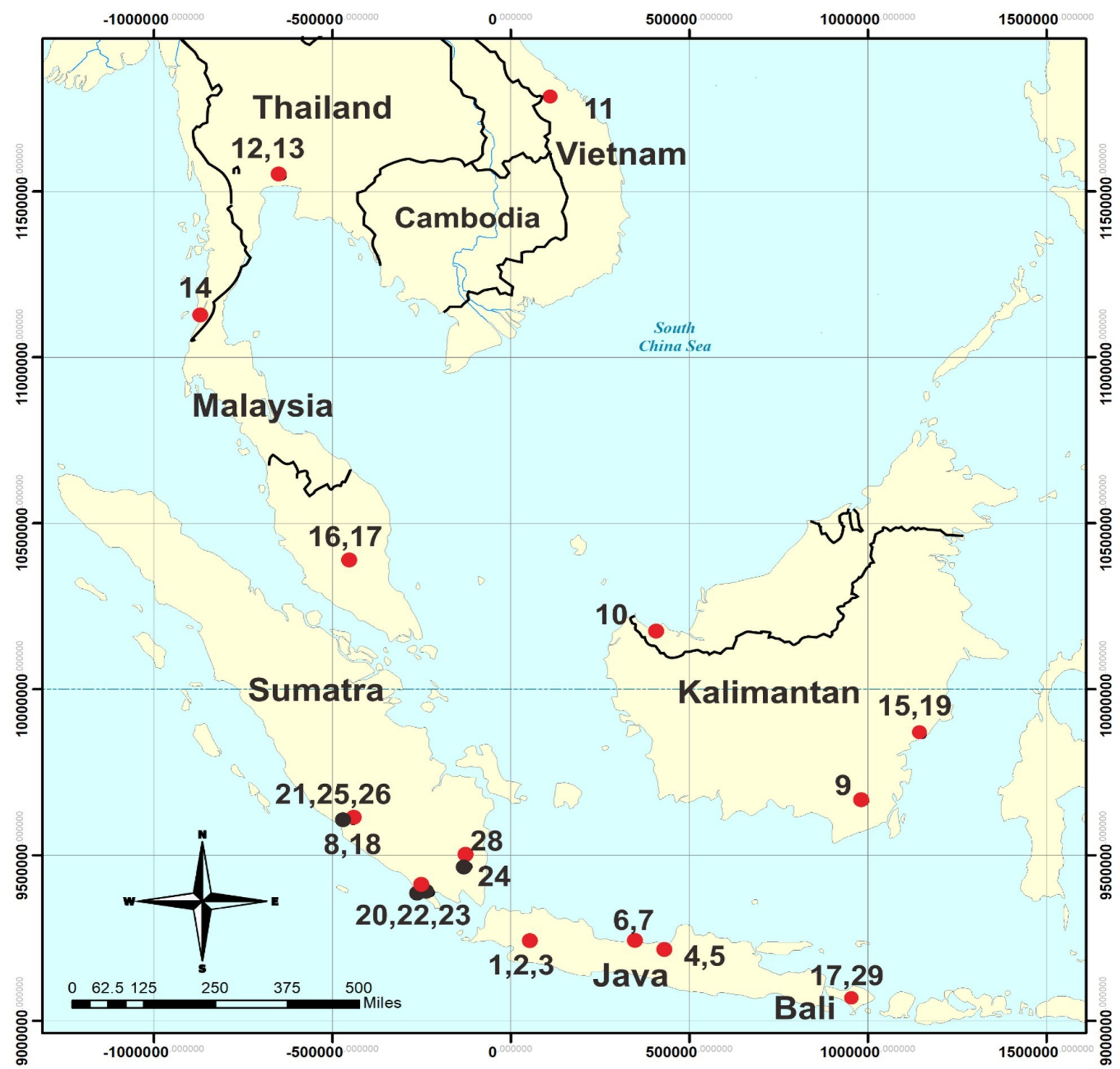

Figure 1. Map of the Sunda Shelf showing sampling localities of Microhyla gadjahmadai sp. nov. in Sumatra (black) and those of samples with Genbank sequences used in this study (red). Sample numbers correspond to those in Table 1(Map modified from ArcGIS 10.2 Desktop Map, October 9, 2018). 


\section{RESULTS}

We obtained 1693 bp of the $12 \mathrm{~S}$ and $16 \mathrm{~S}$ rRNA gene fragments for 29 samples, including outgroups. Of the 1693 nucleotide sites, 611 were variable and 443 were parsimoniously informative. The ML analysis produced a topology a high log likelihood of 9808.0088, a gamma shape parameter of 0.2071 , and nucleotide frequencies of $\mathrm{A}=0.328$, $\mathrm{C}=0.254, \mathrm{G}=0.186$, and $\mathrm{T}=0.232$. The $\mathrm{BI}$ analysis had similar calculated nucleotide frequencies: $\mathrm{A}=0.348, \mathrm{C}=0.244, \mathrm{G}=0.171, \mathrm{~T}=0.236$, and a gamma shape parameter, 0.2047 . All analyses produced the same topologies and only the ML tree is shown (Fig. 2). Microhyla cf. achatina from Sumatra was recovered as sister to M. achatina from Java (supported clade NJ: 100\%, ML: 99\% and BI: 100\%) and deeply nested with Microhyla sp. 3, genbank sequence from Matsui et al. (2011) (supported clade NJ: 98\%, ML: 92\% and BI: 99\%). Microhyla cf. achatina from 2 localities were divided into 2 subclades, Bengkulu (NJ: 100\%, ML: 100\% and BI: 100\%) and Lampung (NJ: 100\%, ML: 100\% and BI: 100\%). This species is a monophyletic group, and genetically distinct from other described Microhyla species. Here we named Sumatran population (Microhyla cf. achatina) and Microhyla sp. 3 as Microhyla gadjahmadai sp. nov. (Fig. 2).

Eventhough Microhyla gadjahmadai sp. nov. formed a monophyletic clade with $M$. achatina but genetic distance is higher than threshold. The uncorrected p-distance (partial gene $16 \mathrm{~S}$ rRNA) of $M$. gadjahmadai sp. nov. with other congeners ranged from $4.8-15.0 \%$ (included its sister taxon), while intraspecific genetic distance from 2 localities (Lampung vs Bengkulu) ranged from $0-3.0 \%$ as shown between M. gadjahmadai sp. nov. and Microhyla sp. 3 (Table 2). The threshold for amphibian species delimitation in 16S rRNA has been suggested to be $\geq 3 \%$ by Fouquet et al. (2007). Therefore M. gadjahmadai sp. nov. can be considered as a different species from other congeners.

In morphology analysis, we examined specimens of M. gadjahmadai sp. nov. and its sister taxon M. achatina. Based on PCA result, the two species were separated by first and second axes (Fig. 3) supported by cumulative percentage $70.52 \%$ from three first component. In the univariate analysis, significant differences between two group were found: nostrileyelid length $(\mathrm{N}-\mathrm{EL})(\mathrm{P}=0.007)$ and dark stripe at temporal/postorbital region $(\mathrm{P}=0.001)$.

\section{Systematics}

\section{Microhyla gadjahmadai sp. nov.}

\section{Synonomy:}

Microhyla sp. 3: Matsui et al., 2011, p. 168 \& 171

Holotype. MZB Amph 26081 (Field number ENS 18216), an adult male from Vila Hijau on Curup Lubik, Lingau Road, Rejang Lebong Regency, in the province of Bengkulu, Indonesia $\left(3.452464^{\circ} \mathrm{S}, 102.650485^{\circ}\right.$ E, elevation $1085 \mathrm{~m}$ a.s.l., Fig. 1), collected on 17 July 2015 by E. Wostl, E. N. Smith, G. C. Sarker, and P. Thammachoti. [1.2g in weight] 


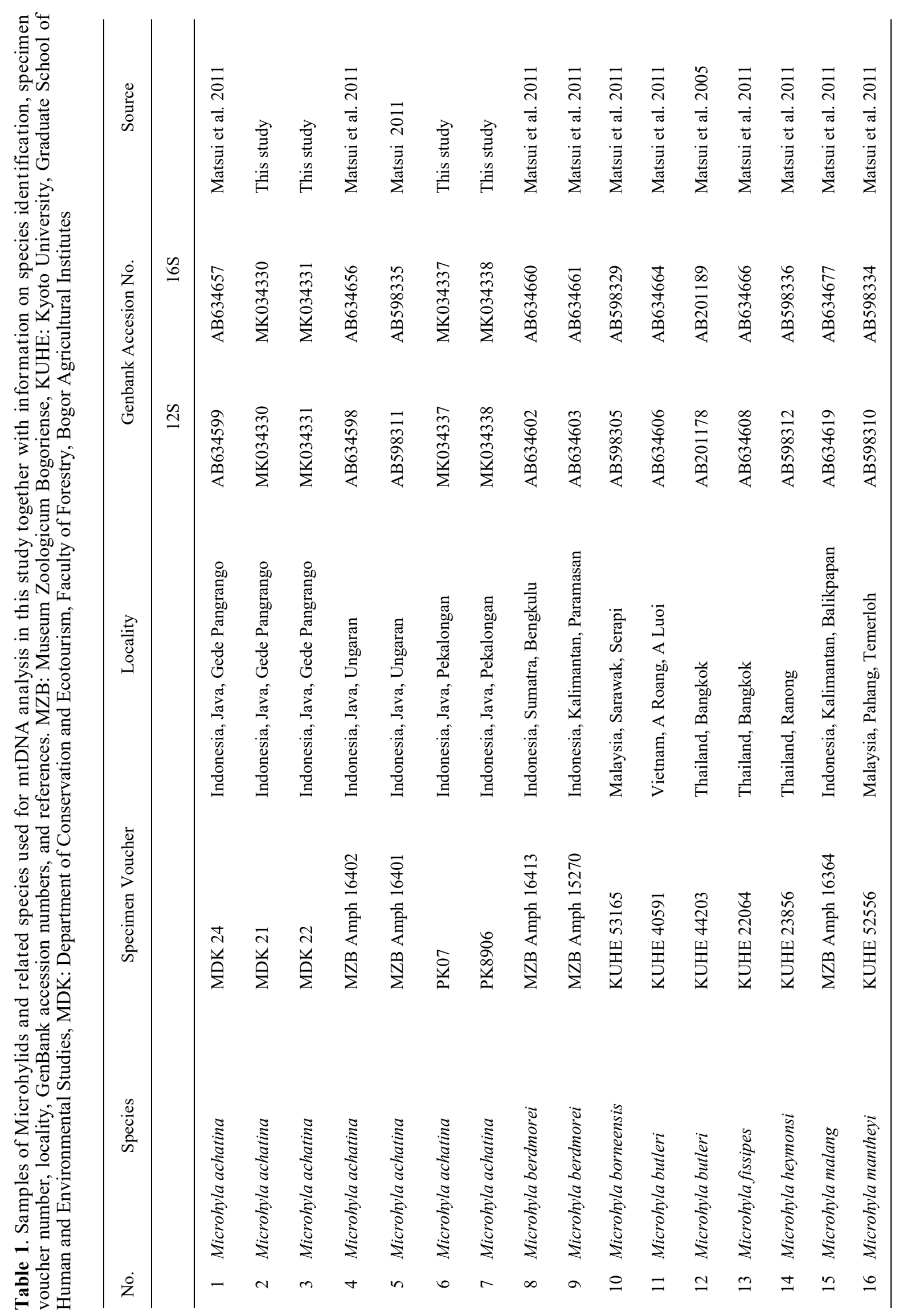




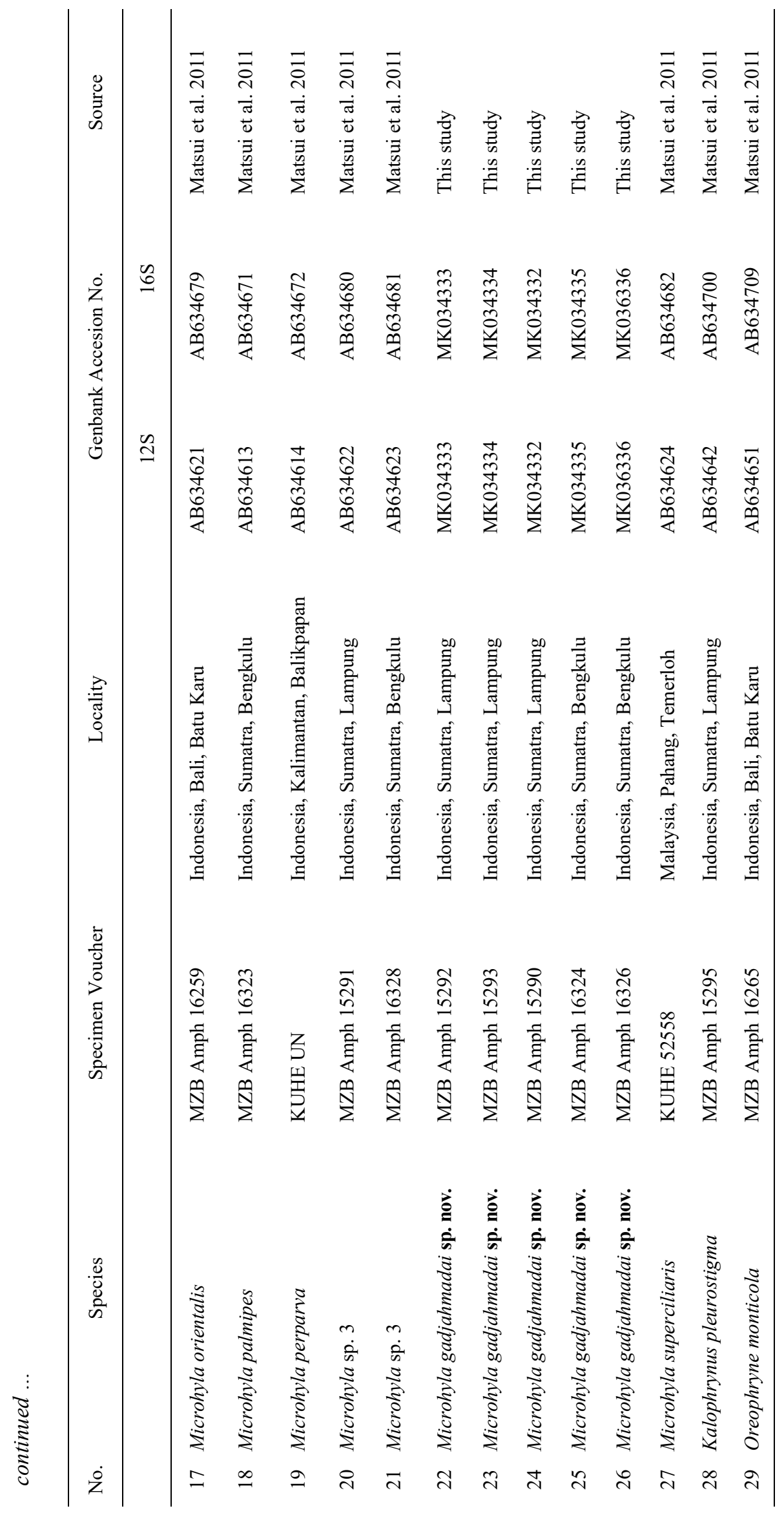




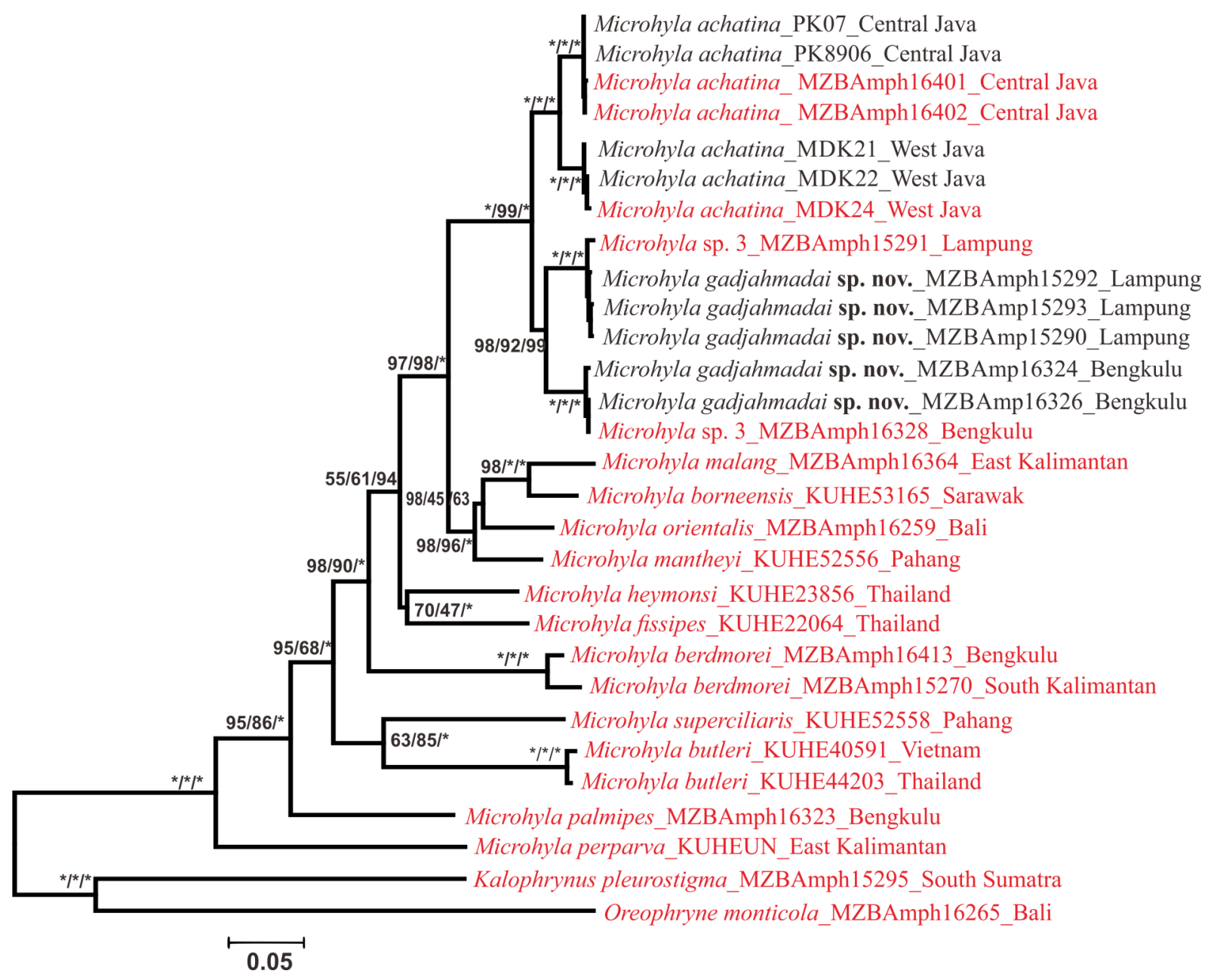

Figure 2. Maximum likelihood phylogeny from $1693 \mathrm{bp}$ of the $12 \mathrm{~S} \& 16 \mathrm{~S}$ rRNA mitochondrial genes for samples of Microhyla gadjahmadai sp. nov. and related species with outgroups. Numbers above or below branches represents bootstrap support for $\mathrm{NJ} / \mathrm{ML}$ and Bayesian Inferences (BI). Asteriks indicate significant bootstrap supports for NJ and ML ( $\geq 70 \%)$ inferences and Bayesian Inference (BI $>95 \%)$. 
Atmaja et al.: A new species of Microhyla (Anura: Microhylidae) from Sumatra

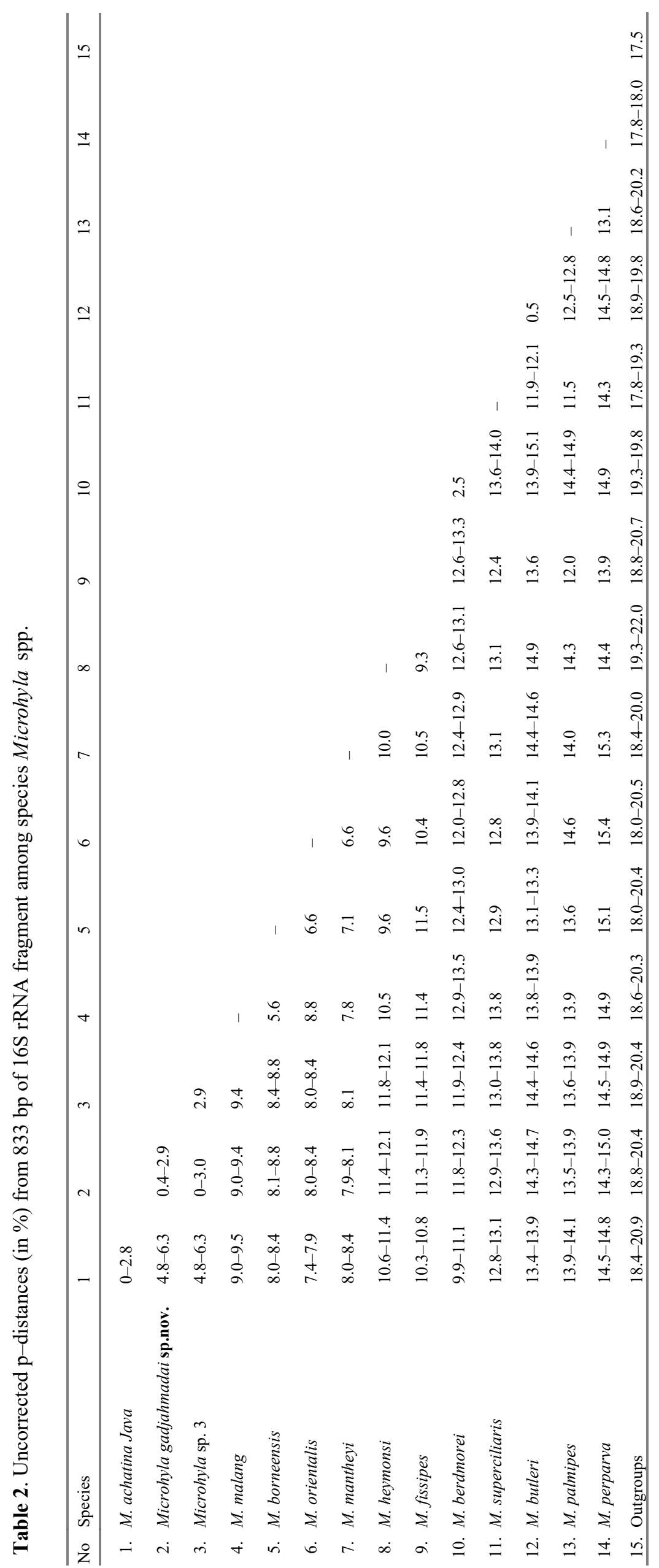




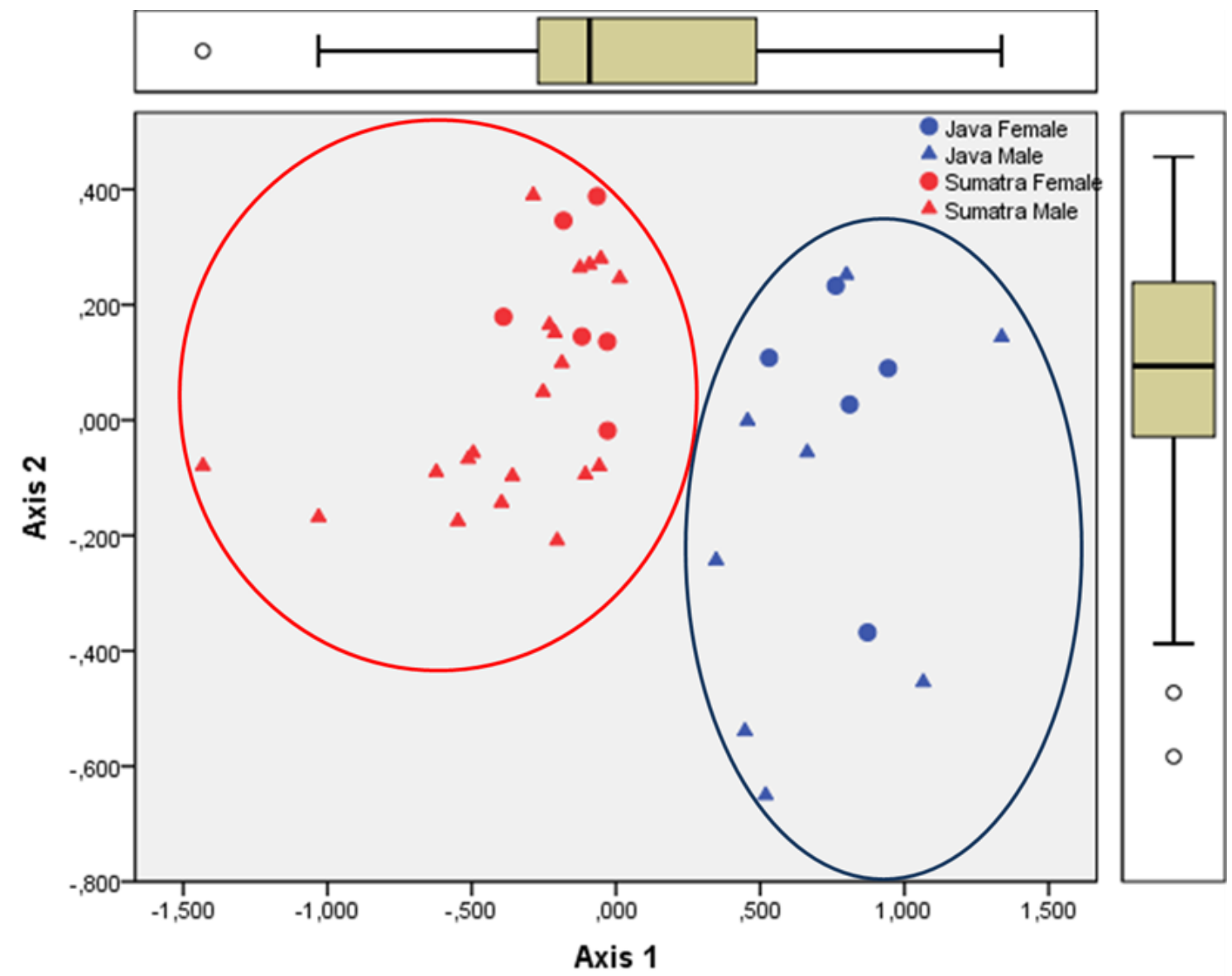

Figure 3. Scatter plot of first and second principal components showing differntiation between Microhyla gadjahmadai sp. nov. from Sumatra (red) and M. achatina from Java (blue). Circles represent females and triangles represent males. The proportion of variance explained by the first three components is $70.52 \%$ ( $\mathrm{PC1}=$ $55.74 \%, \mathrm{PC} 2=7.99 \%, \mathrm{PC} 3=6.96 \%)$. Notice that component 1 accounts for the species variation and component 2 for some of the variation in sex. 
Paratypes. MZB Amph 26078, UTA A-65741, UTA A-65743, three adult males from Bukit Kaba, Rejang Lebong Regency, in the province of Bengkulu, Indonesia $\left(3.49259^{\circ}\right.$ $\mathrm{S}, 102.63589^{\circ} \mathrm{E}$, elevation $1380 \mathrm{~m}$ a.s.1.; $3.49210^{\circ} \mathrm{S}, 102.63516^{\circ} \mathrm{E}$, elevation $1351 \mathrm{~m}$ a.s.l.; $3.49446^{\circ} \mathrm{S}, 102.63684^{\circ} \mathrm{E}, 1358 \mathrm{~m}$ a.s.l; respectively), collected on 16 July 2015 by E. N. Smith, U. Smart, and S. Sianturi. UTA A-65744, one adult male from Bengkulu Utara Regency, Road Maura Aman-Argamakmu (3.20576 ${ }^{\circ} \mathrm{S}, 102.14232^{\circ}$ E, $833 \mathrm{~m}$ a.s.1.), collected on 19 July 2015 by E. N. Smith, U. Smart, and G. Pradana. MZB Amph 16326-16327, two adult females and MZB Amph 16325, MZB Amph 16328, two adult males from Suro Lembak Village, Ujan Mas District, Kepahiang Regency, in the province of Bengkulu, Indonesia $\left(3.59^{\circ} \mathrm{S}, 102.58^{\circ} \mathrm{E}\right.$, ca. $750 \mathrm{~m}$ a.s.1), collected on 20 July 2010 by A. Hamidy and Nurrohim. MZB Amph 16324, one adult female from Batu Ampar Village, Merigi District, Kepahiang Regency, in the province of Bengkulu, Indonesia $\left(3.31^{\circ} \mathrm{S}, 102.33^{\circ} \mathrm{E}\right)$, collected on 18 July 2010 by A. Hamidy and Nurrohim.

Etymology. The specific epithet honors the military leader and hero Gadjah Mada, who in the fourteenth century unified the whole of the Nusantara (i.e., Malay Archipelago) under the Javanese rule of the Hindu Majapahit Empire.

Diagnosis. The new species is assigned to Microhyla because of having a small size (SVL $<30 \mathrm{~mm}$ ), narrow head and mouth, tympanum hidden by skin, maxillary and vomerine teeth absent, and a reduced first finger length (Tschudi, 1838, Malkmus et al., 2002). Microhyla gadjahmadai sp. nov. is diagnosable from its congeners by having a medium size (for Microhyla, SVL adult males 18.2-21.3 mm, adult females 20.4-25.5 mm), stout body, a nostril-eyelid length of half the length of the snout, a single outer palmar tubercle, the tibiotarsal articulation reaching the center of eye, finger and toe tips dilated, median longitudinal grooves on dorsum, relatively reduced toe webbing (free of webbing: one and three quarter phalanges on outer surface of second toe, three phalanges on inner and outer surface of third toe, four phalanges on inner and outer surfaces of fourth toe, and two and three quarter phalanges on inner surface of fifth toe), and a thin-short dark temporal stripe over a wider cream stripe, extending from postorbital area to insertion of forelimb.

Description of holotype (measurements in mm). SVL 20.6; habitus stout; head as wide as long (5.8 vs 5.9); snout dorsally rounded; eye (2.0) shorter than snout (3.3), slightly longer than nostril to eyelid length (1.8); lore sloping and slightly convex; nostril distinct in lateral view, located below canthus rostralis, closer to tip of the snout (1.6) than to eye (1.8); interorbital distance (2.7) wider than internarial distance (2.2), and twice upper eyelid (1.1); tympanum hidden; supratympanic fold visible, extending from posterior corner of eye to forelimb insertion; vocal slits and vocal sacs present; dorsum and anal region with low tubercles; abdomen and inner surface of thigh smooth. 
Forelimb short (FLL 12.2; 59.1\% of SVL); fingers thin, free of web, with poorly developed skin fringes on both sides of fingers II-IV; finger tips weakly dilated, dorsally with median longitudinal groove; fingers lengths: III (2.8) > IV (1.9) > II (1.3) > I (0.9); single outer palmar tubercle (1.1), larger than inner (0.9); subarticular tubercles distinct and rounded, formula: 1, 1, 2, 2; nuptial pad absent.

Hindlimb long $(43.1 ; 209.0 \%$ of SVL) about three times length of forelimb; tibia (13.0) longer than foot (10.9); tibiotarsal articulation reaching center of eye; toe III length 0.8 ; toe tips distincly dilated, spatulate, dorsally with median longitudinal groove; web formula I 2 -2 $\frac{1 / 4}{4}$ II 13/4-3 III 3-4 IV 4-23/4 V; subarticular tubercles prominent, somewhat oval, formula: $1,1,2,3,2$; inner metatarsal tubercle oval, length (0.8) about half of first toe (2.0); outer metatarsal tubercle (0.6) smaller than inner.

Coloration. In life, dorsum light brown; cream vertebral line from snout to anal region, wider at snout tip; region from snout to mid supraorbital region cream; iris bright gold with faint black reticulation; a thin-short dark temporal stripe over a wider cream stripe, extending from postorbital area to insertion of forelimb; body dorsum with brown mark, bordered by a cream line, extending from between orbits to iliac area, laterally extending to cover posterior half of supraorbital area and suprascapular region, and extending posterolaterally from middorsum towards groin and from midsacral area towards waist; dark sepia lateral band extending from above arm to half length of flank, darker and boldly edged above, fading towards venter; two inconspicuous and thin dark bars on hindlimb, over thiegh and leg; throat dark brown, with some cream peppering; chest white-cream; abdomen, inguinal area, and proximal ventral region of limbs transluscent pink (Fig. 4A). In preservative, pattern did not change dramatically, only becaming darker (Figs. 5-6).

Variation. See Table 3 for morphometric data from 18 male and six female adults. Half of the examined specimens are darkly pigmented from throat to pectoral and the rest have same pattern with holotype. Stripe at lateral body: nine specimens with a stripe extends from above arm to groin and the rest to mid body. Dark bars on limbs: mostly with two clear dark bars and some specimens with one or two addition faded dark bars. Webbing formula was stable for the outer and inner side of fourth toe with four phalanges free, but slight variations are recognized in other positions e.g., in a female paratype (MZB Amph 16326), one half phalanges free on first toe, while male holotype (MZB Amph 26081) has two free phalanges. This variation is not consistent based on sex.

Range. The new species is curently known from Bengkulu (Rejang Lebong, Bengkulu Utara, and Kepahiang Regency), Lampung (Tanggamus and Lampung Tengah Regency), and South Sumatra (Muara Enim Regency and Pagar Alam City) province with elevation range from $700-1647 \mathrm{~m}$ a.s.1. 
Comparisons. Microhyla gadjahmadai sp. nov. can be differentiated from genetically close members of the M. achatina group of Matsui et al. (2011) and Sumatran Microhyla as following characters: The new species differs from M. achatina by having thinshort dark stripe at temporal/postorbital region (vs. dark stripe strong and short/longer (almost reach up to shoulder) (Fig. 4A vs 4B) and N-EL half sized of SL (vs. N-EL more than half of $\mathrm{SL}$ ) . From $M$. orientalis by having lateral band strong and clearly bordered above, also more developed fifth toe web (2.75 free phalages) [vs. a lateral dark band vaguely bordered, and less developed fifth toe web ( 3 free phalages)]. The new species differs from M. borneensis by larger body size, male SVL 18.2-21.3 mm (vs. 11.0-13.2 mm) and less developed toe webbing. Differs from M. malang and M. mantheyi by less developed toe webbing, with the fifth toe having two and three quarter phalanges free (vs. one phalange free). The new species differs from $M$. heymonsi Vogt by having two metacarpal tubercles and lacking loreal mask (vs. having three tubercles, a black band covering side of head, one or two pairs of black marks on sides of vertebral line, two black spots bisecting vertebral line). From M. fissipes Boulenger, M. mixtura Liu and Hu, M. okinavensis Stejneger, and M. pulchra (Hallowell), the new species differs by having dilated finger and toe tips with dorsal median longitudinal grooves (vs. digiti tips not dilated and grooves entirely absent or present only on toes). From M. berdmorei (Blyth), the new species differs by less developed toe webbing (vs. toe webbed to the tips). Finally, from M. palmipes and M. superciliaris, the new species differs by lacking a supraciliary tubercle, less developed toe webbing, and the presence of dorsal median grooves on digiti tips (vs. having a supraciliary tubercle, more developed toe webbing, and toe tips with circum marginal grooves).

Natural history. Microhyla gadjahmadai sp. nov. is distributed in southern Sumatra, inhabiting from primary forest, secondary forest and open area such as farming area (Bengkulu). The tadpole and advertisement call of this species are still unknown.

\section{DISCUSSION}

In a previous study of phylogenetic analysis of microhylids in Oriental region, Matsui et al. (2011) recognized three unidentified taxa nested within Microhyla group. One of them is Microhyla sp. 3 collected from Bengkulu and Lampung. Microhyla sp. 3 formed a clade with $M$. achatina supported by significant bootstrap values in all phylogenetic trees. Although in the same clade, Microhyla sp. 3 and M. achatina had large genetic distance (5.56.6\%) (Matsui et al., 2011). In accordance with phylogenetic tree of Matsui et al. (2011), our analyses resolved the taxonomic status of Microhyla sp 3. and we here described it as Microhyla gadjahmadai sp. nov. This species is a sister taxon to M. achatina with uncorrected 


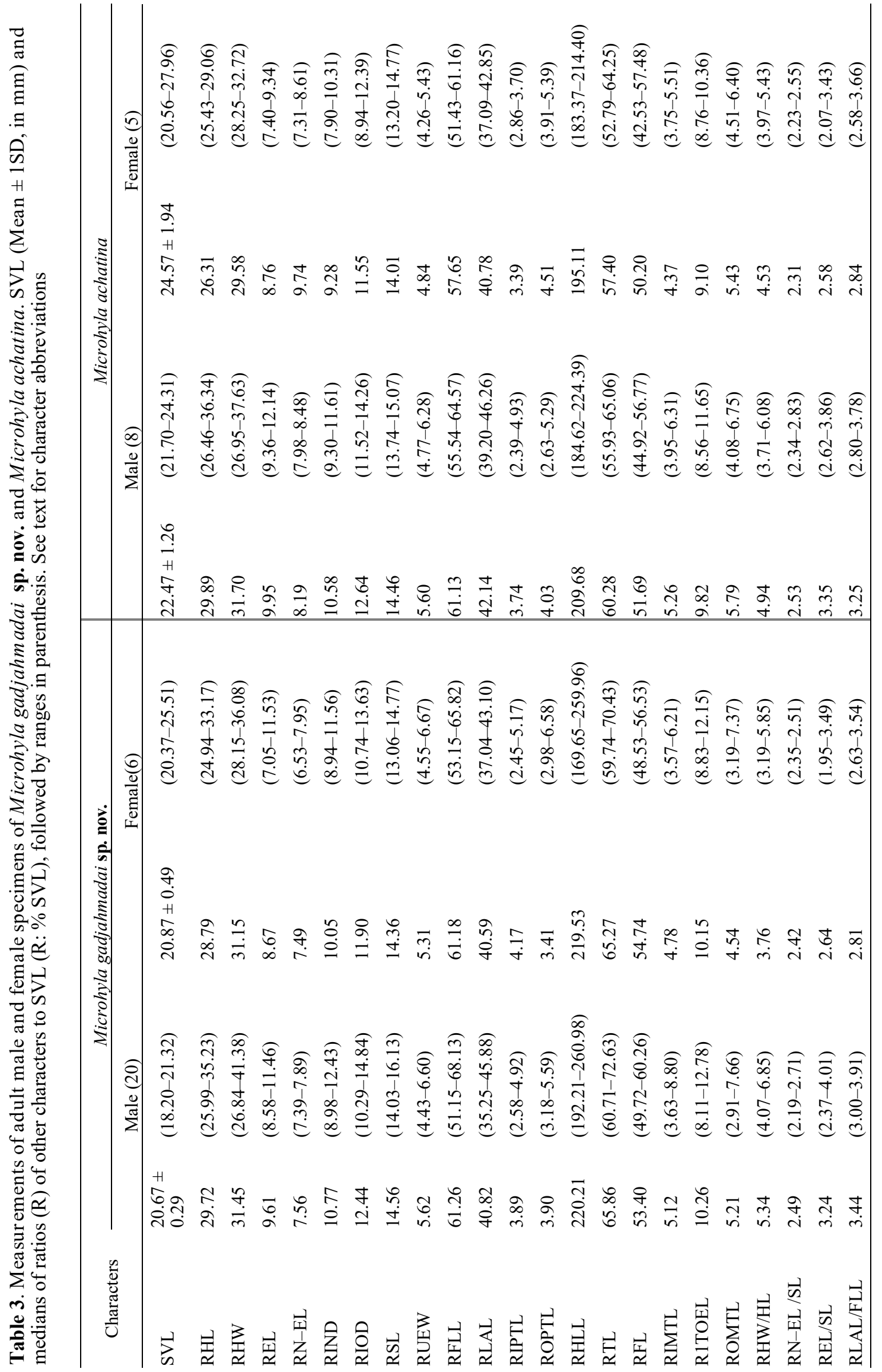




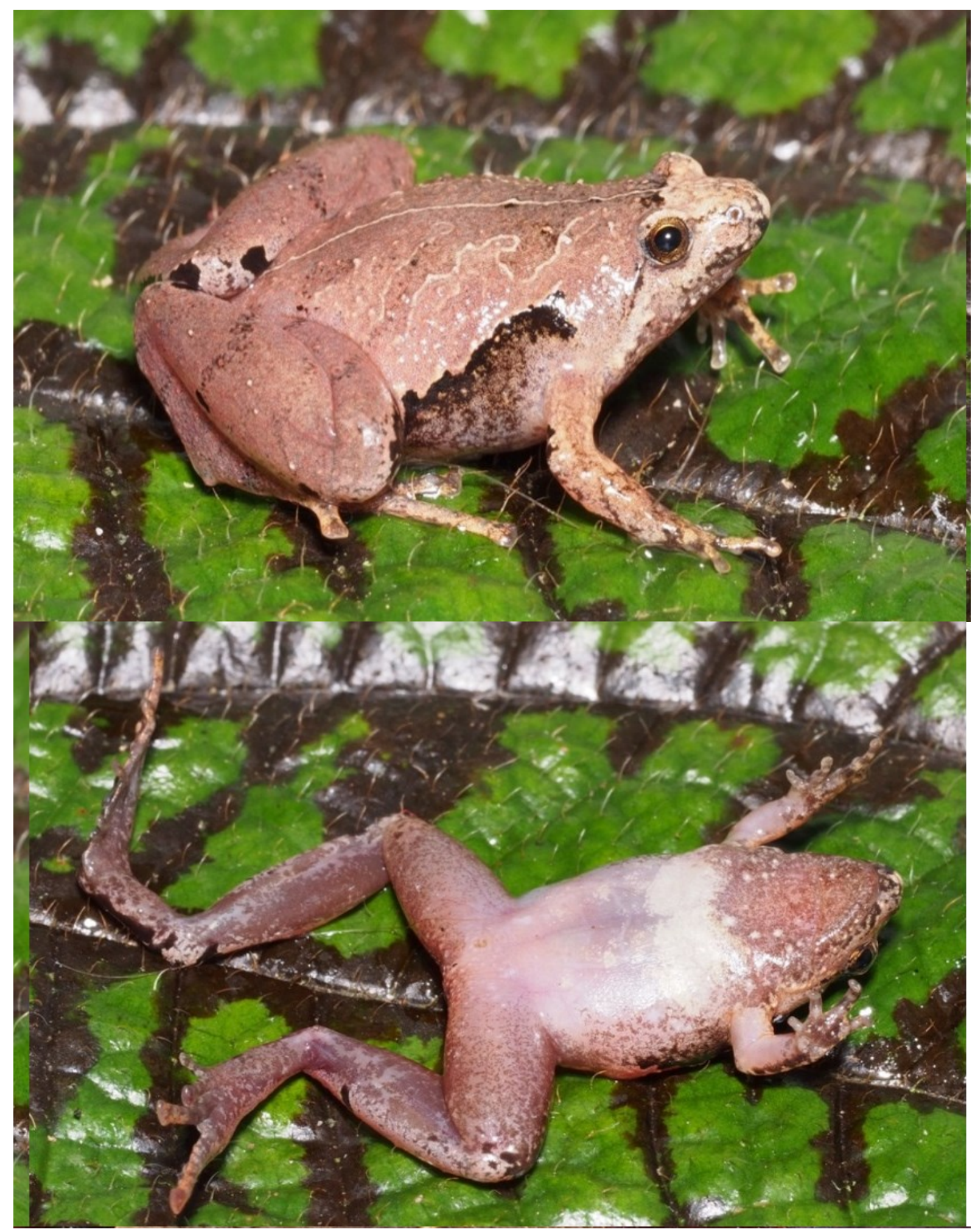

Figure 4 A. In life, dorsolateral and ventral view of male holotype of Microhyla gadjahmadai sp. nov. (MZB Amph 26081) from Rejang Lebong Regency, in the province of Bengkulu, Sumatra, Indonesia (Photographs by E. N. Smith). 


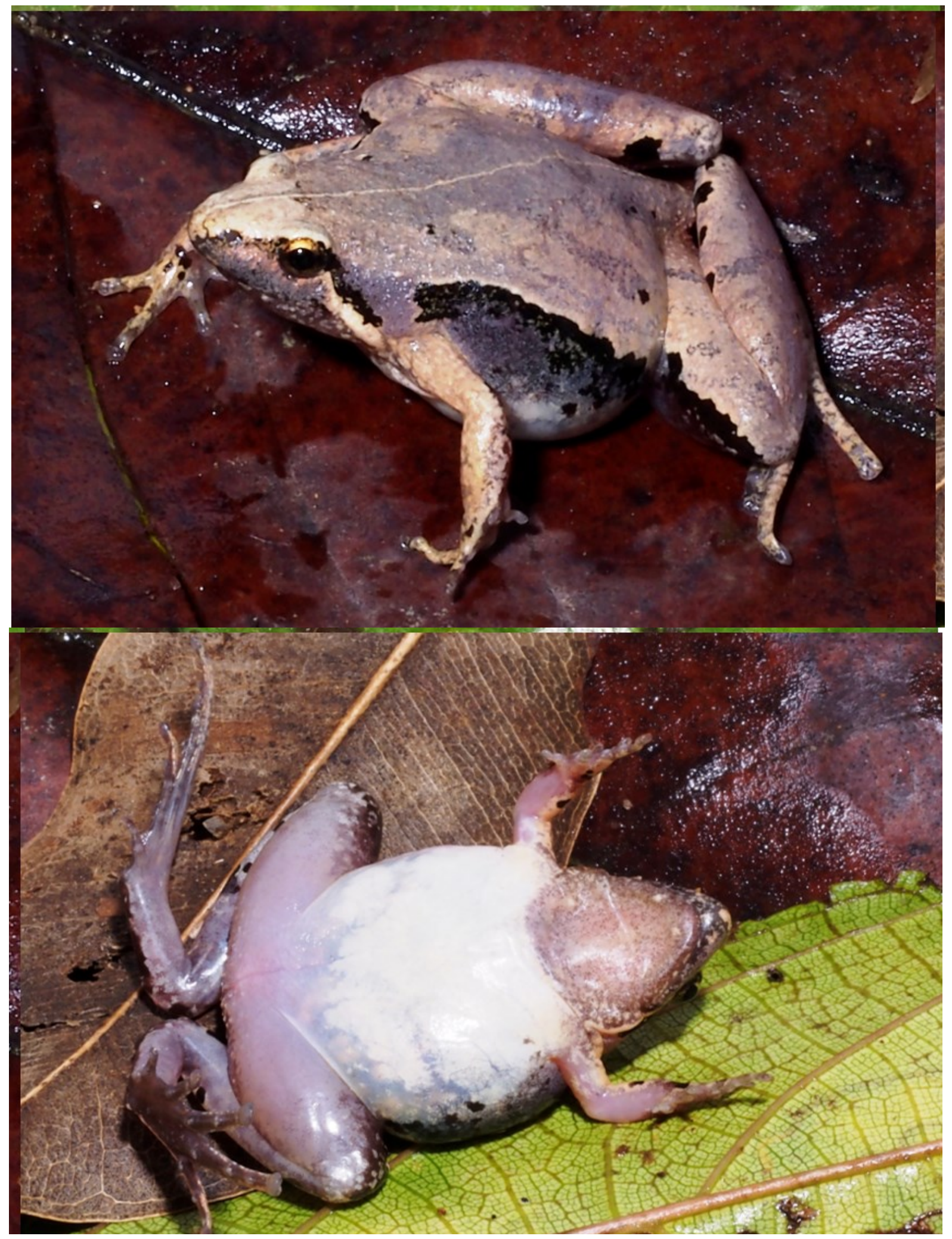

Figure 4 B. In life, dorsolateral and ventral view of Microhyla achatina (MZB Amph 24099) from Pandeglang Regency, in the province of Banten, Java, Indonesia (Photographs by E. N. Smith). 


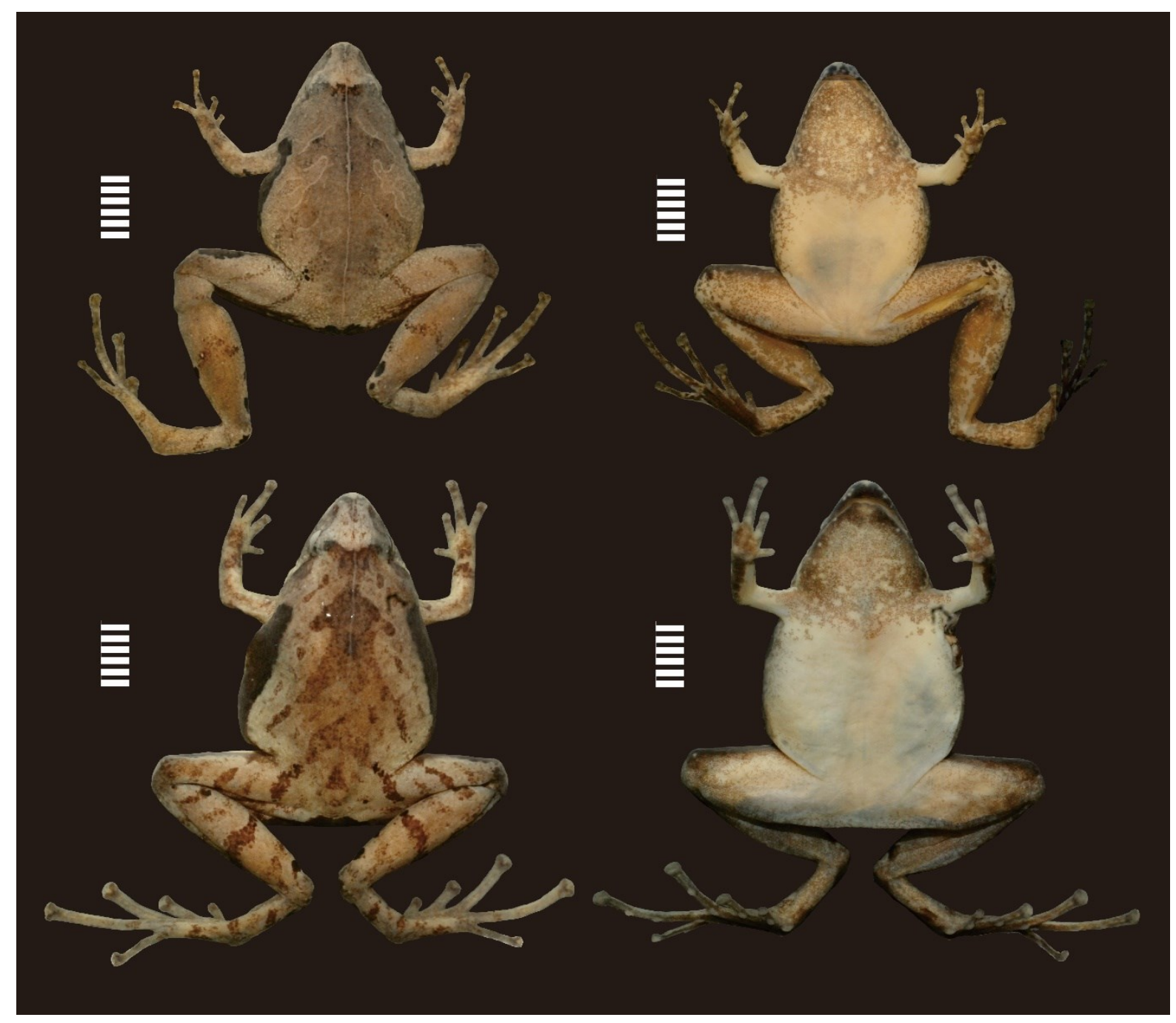

Figure 5. Dorsal, ventral, male holotype of Microhyla gadjahmadai sp. nov.-MZB Amph 26081 (SVL 20.61 $\mathrm{mm}$ ) and female paratype-MZB Amph 16326 (SVL $25.51 \mathrm{~mm}$ ). Scale bar = $5 \mathrm{~mm}$. (Photographs by V.Y. Atmaja). 


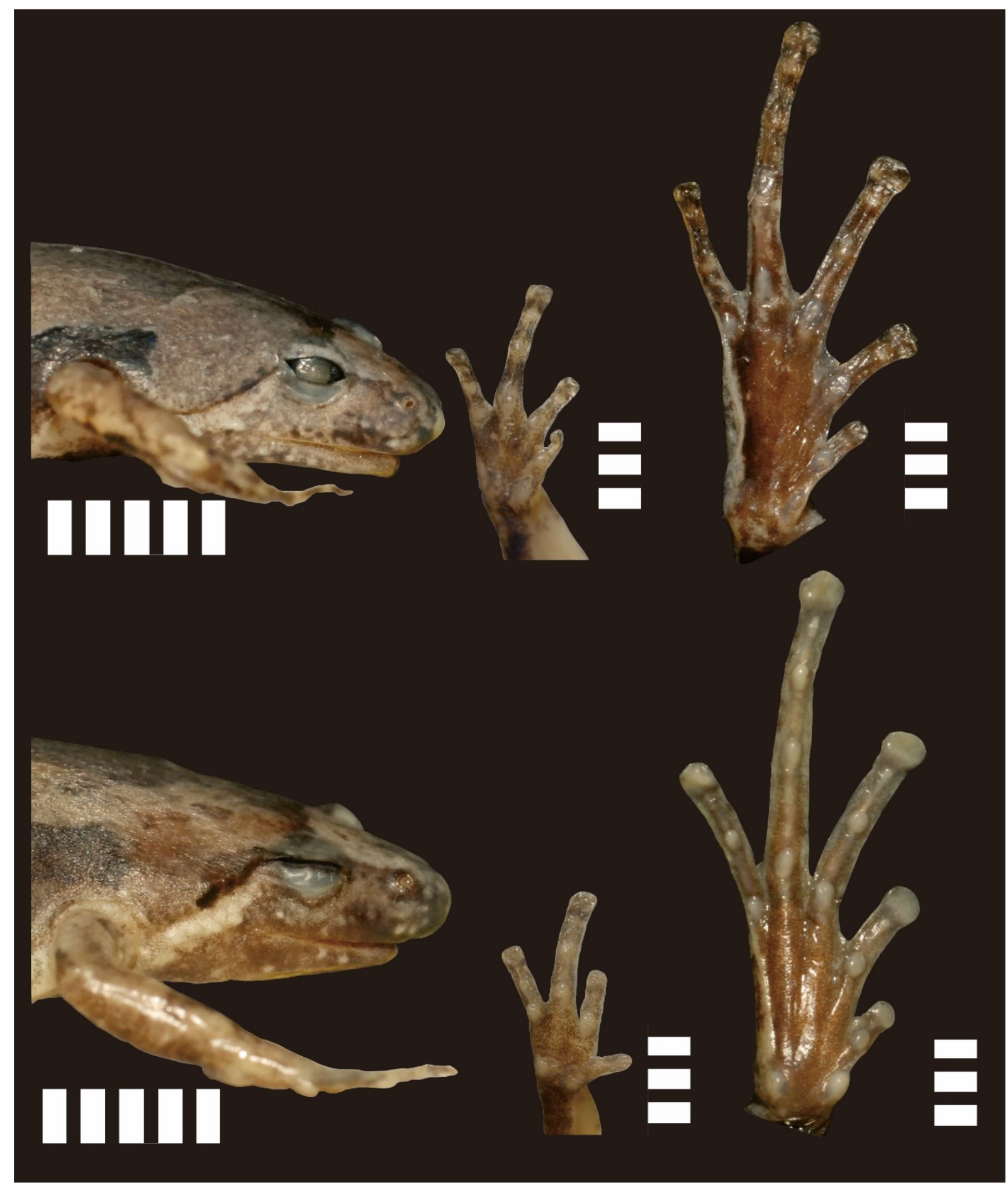

Figure 6. Lateral head, ventral right hand and ventral right foot views of holotype of Microhyla gadjahmadai sp. nov.-MZB Amph 26081 (SVL $20.61 \mathrm{~mm}$ ) and female paratype-MZB Amph 16326 (SVL $25.51 \mathrm{~mm}$ ). Scale bar $=5 \mathrm{~mm}$. (Photographs by V.Y. Atmaja). 
p-distance ranging from $4.8-6.3 \%$. Together with $M$. achatina, M. gadjahmadai sp. nov is closer to the M. borneensis subgroup (suggested in Matsui et al., 2013): M. borneensis, $M$. malang, M. orientalis, and M. mantheyi (8.0-9.4\%) than to other Sumatran Microhyla (M. berdmorei, M. fissipes, M. heymonsi, M. palmipes and M. superciliaris).

Sumatra had been explored for its amphibian diversities for long decades, but new species are continuously discovered from this Island until now. At least two new endemic genera (Sigalegalephrynus and Sumaterana) and 14 species of frogs have been described from this island in the last five years (Matsui et al., 2014; Riyanto \& Kurniati, 2014; Streicher et al., 2014; Hamidy \& Kurniati, 2015; Smart et al., 2017; Wostl et al., 2017; Arifin et al., 2018a $\&$ 2018b; Munir et al., 2018). The finding of Microhyla gadjahmadai sp. nov. has contributed to increase the number of amphibian species in Sumatra to $95.45 \%$ of which (42 species) are endemic to the Island. The unique geological formation of Bukit Barisan Mountains may have a causal relationship with speciation and endemism across the region (Hamidy \& Kurniati, 2015).

Over the two decades (from 1990-2010), tropical rain forest decreases by $40 \%$ in Sumatra Island (Margono et al., 2012). The species undergo climate change, habitat destruction (loss, degradation, and fragmentation) and resulting extinction of the species. Furthermore, the right conservation management plans are needed to improve the protection of habitat and species that have been or have not been described.

\section{ACKNOWLEDGMENTS}

We thank two anonymous reviewers for all comments to improve the manuscript. We are very grateful to Mirza D. Kusrini (Bogor Agricultural Institute) for permission to examine their specimen collections. We thank Misbahul Munir and Yuli S. Fitriana for the discussion, Rini Aini for laboratory assistance. AH thank Sasi Kirono, Dwi Susanto for fieldwork assistance in 2008 fieldwork, Nia Kurniawan and A. M. Kadafi (MIPAUB), U. Arifin (ITB), W. Trilaksono and Irvan Sidik (MZB), M. B. Harvey, G. Baranza, K. A. O’Connell, C. Franklin, U. Smart, E. Wostl, G. C. Sarker, and P. Thammachoti (UTA), S. Sianturi (IPB), Nurrohim for all supports in fieldworks. The National Science Foundation supported museum visits and fieldworks in Sumatra from 2013 to 2016 through a grant to Eric N. Smith and Michael B. Harvey (DEB-1146324). Amir Hamidy thanks the Indonesian Fauna Barcoding Project Grant (DIPA Puslit Biologi LIPI 2016). 


\section{REFERENCES}

Arifin, U., Cahyadi, G., Smart, U., Jankowski, A. \& Haas, A. 2018a. A new species of the genus Pulchrana Dubois, 1992 (Amphibia: Ranidae) from Sumatra, Indonesia. Raffles Bulletin of Zoology, 66: 277-299.

Arifin, U., Smart, U., Hertwig, S.T., Smith, E.N., Iskandar, D.T. \& Haas, A. 2018b. Molecular phylogenetic analysis of a taxonomically unstable ranid from Sumatra, Indonesia, reveals a new genus with gastromyzophorous tadpoles and two new species. Zoosystematics and Evolution, 94: 163-193.

Environmental Systems Research Institute (ESRI). 2014. ArcGIS Desktop Help 10.2 Geostatistical Analyst. California: Redlands.

Fouquet, A., Gilles, A., Vences, M., Marty, C., Blanc, M. \& Gemmell, N.J. 2007. Underestimation of species richness in Neotropical frogs revealed by mtDNA analyses. PLoS ONE, 2 (10): e1109.

Frost, D.R. 2017. Amphibian species of the world: an online reference. Version 6.0. http:// research.amnh.org/herpetology/amphibia/index.html 7 November 2017.

Hamidy, A. \& Kurniati, H. 2015. A new species of tree frog genus Rhacophorus from Sumatra, Indonesia (Amphibia, Anura). Zootaxa, 3947: 49-66.

Hedges, S.B., Nussbaum, R.A. \& Maxson, L.R. 1993. Caecilian phylogeny biogeography inferred from mitochondrial DNA sequences of the 12S rRNA and 16S rRNA genes (Amphibia: Gymnophiona). Herpetology Monographs, 7: 64-76.

Hillis, D.M. \& Bull, J.J. 1993. An empirical test of bootstrapping as a method for assessing confidence in phylogenetic analysis. Systematic Biology, 42:182-192.

IBM Corp. 2013. IBM SPSS Statistics for Windows, Version 22.0. New York: Armonk.

Jobb, G., von Haeseler, A. \& Strimmer, K. 2004. Treefinder: a powerful graphical analysis environment for molecular phylogenetics. BMC Evolution Biology, 4: 18.

Kumar, S., Stecher, G. \& Tamura, K. 2016. MEGA7: Molecular evolutionary genetics analysis version 7.0 for bigger datasets. Molecular biology and evolution, 33(7): 1870-1874.

Leaché, A.D. \& Reeder, T.W. 2002. Molecular systematics of the Eastern Fence Lizard (Sceloporus undulatus): a comparison of parsimony, likelihood, and Bayesian approaches. Systematic Biology, 51: 44-68.

Malkmus, R., Manthey, U., Vogel, G. \& Hoffmann. P. 2002. Amphibians and Reptiles of Mount Kinabalu (North Borneo). Koeltz Scientific Books: pp. 329-332.

Margono, B.A., Turubanova, S., Zhuravleva, I., Potapov, P., Tyukavina, A., Baccini, A., Goetz, S. \& Hansen, M.C. 2012. Mapping and monitoring deforestation and forest degradation in Sumatra (Indonesia) using Landsat time series data sets from 1990 to 2010. Environmental Research Letters, 7: 034010.

Matsui, M. 1984. Morphometric Variation Analyses and Revision of the Japanese Toads (Genus Bufo, Bufonidae). Tokyo (Japan): Kyoto University Press: pp. 236-239.

Matsui, M., Ito, H., Shimada, T., Ota, H., Saidapur, S.K., Khonsue, W., Tanaka-Ueno, T. \& Wu, G.F. 2005. Taxonomic relationships within the Pan-Oriental narrow-mouth toad, Microhyla ornata as revealed by mtDNA analysis (Amphibia, Anura, Microhylidae). Zoological Science, 22: 489-495.

Matsui, M. 2011. Taxonomic revision of one of the Old World's smallest frogs, with description of a new Bornean Microhyla (Amphibia, Microhylidae). Zootaxa, 2814: 33-49.

Matsui, M., Hamidy, A., Belabut, D.M., Ahmad, N., Panha, S., Sudin, A., Khonsue, W., Oh, H.S., Yong, H.S., Jiang, J.P. \& Nishikawa, K. 2011. Systematic relationships of Oriental tiny frogs of the family Microhylidae (Amphibia, Anura) as revealed by mtDNA genealogy. Molecular Phylogenetics and Evolution, 61: 167-176. 
Matsui, M., Hamidy, A. \& Eto, K. 2013. Description of a new species of Microhyla from Bali, Indonesia (Amphibia, Anura). Zootaxa, 3670(4): 579-590.

Matsui, M., Hamidy, A. \& Kuraishi, N. 2014. A new species of Polypedates from Sumatra, Indonesia (Amphibia: Anura). Species Diversity, 19: 1-7.

McKay, J. L. 2006. A Field Guide to the A mphibians and Reptiles of Bali. Florida: Krieger Publishing Company: pp. 33-35.

Munir, M., Hamidy, A., Farajallah, A. \& Smith, E.N. 2018. A new Megophrys Kuhl and Van Hasselt (Amphibia: Megophryidae) from southwestern Sumatra, Indonesia. Zootaxa, 4442: 389-412.

Natus, I.R. 2005. Biodiversity and Endemic Centres of Indonesian Terrestrial Vertebrates. PhD. Dissertation. Facbereich VI (Geographic/Geowissenchaften). Trier: Trier University: pp. 33-34.

Parker, H.W. 1934. A Monograph of the Frogs of the Family Microhylidae. London: Trustees of the British Museum: pp. 127-139.

Pradana, T.G. 2017. Hubungan Filogenetik Microhyla, Tschudi 1839 dari Sumatra Berdasarkan Gen 16s rRNA (Tesis). Bogor [ID]: Institut Pertanian Bogor: pp. 6-11.

Riyanto, A. \& Kurniati, H. 2014. Three new species of Chiromantis Peters 1854 (Anura: Rhacophoridae). Russian Journal of Herpetology, 21: 65-73.

Ronquist, F. \& Huelsenbeck, J.P. 2003. MrBayes 3: Bayesian phylogenetic inference under mixed models. Bioinformatics, 19(12): 1572-1574.

Savage, J.M. \& Heyer, W.R. 1967. Variation and distribution in the tree-frog genus Phyllomedusa. Beitrage zur Neotropischen Fauna, 5(2): 111-131.

Smart, U., Sarker, G.C., Arifin, U., Harvey, M.B., Sidik, I., Hamidy, A., Kurniawan, N. \& Smith, E.N. 2017. A new genus and two new species of arboreal toads from the highlands of Sumatra with a phylogeny of Sundaland toad genera. Herpetologica, 73: 63-75.

Streicher, J.W., Hamidy, A., Harvey, M.B., Anders, B., Shaney, K.J., Kurniawan, N. \& Smith, E.N. 2014. Mitochondrial DNA reveals a new species of parachuting frog (Rhacophoridae: Rhacophorus) from Sumatra. Zootaxa, 3878: 351-365.

Tanabe, A.S. 2011. Kakusan4 and Aminosan: two programs for comparing nonpartitioned, proportional, and separate models for combined molecular phylogenetic analyses of multilocus sequence data. Molecular Ecology Resources, 11: 914-921.

Thorpe, R.S. 1975. Quantitative handling of characters useful in snake systematics with particular reference to intraspecific variation in the Ringed Snakes Natrix natrix (L.). Biological Journal of the Linnean Society, 7: 27-43.

Tschudi, J. J. v. 1838. Classification der Batrachier mit Berücksichtigung der fossilen Thiere dieser Abtheilung der Reptilien. Neuchâtel: Petitpierre: pp. 28-29.

van Kampen, P.N. 1923. The A mphibia of the Indo-Australian Archipelago. Leiden: E. Brill Limited: pp. 278.

Wostl, E., Riyanto, A., Hamidy, A., Kurniawan, N., Smith, E.N. \& Harvey, M.B. 2017. A taxonomic revision of the Philautus (Anura: Rhacophoridae) of Sumatra with the description of four new species. Herpetological Monographs, 31: 98-141. 
APPENDIX 1. Comparative material examined

Microhyla achatina (Java, Indonesia, $\mathrm{N}=13$ ): Banten Province: Pandeglang Regency, Pulosari Mountain $6.32965^{\circ} \mathrm{S}, 105.96696^{\circ} \mathrm{E}, 682 \mathrm{~m}$ a.s.l.-MZB Amph 23095-23096 (female); West Java Province: Sukabumi Regency, Vicinity of Cisolok Hot spring, $6.93331^{\circ} \mathrm{S}, 106.45305^{\circ} \mathrm{E}, 99 \mathrm{~m}$ a.s.l. -MZB Amph 23097 (female); Central Java Province: Karanganyar Regency, Ngargoyoso District, Sukuh Temple, $7.63129^{\circ} \mathrm{S}, 111.1352^{\circ} \mathrm{E}, 1169 \mathrm{~m}$ a.s.l.-MZB Amph 27115 (male); Banyumas Regency, Baturaden District, Kemutuk Village, Baturaden Botanical Garden, $7.31306^{\circ} \mathrm{S}, 109.2334^{\circ} \mathrm{E}$, 650 m a.s.1.-MZB Amph 27116-27118 (male); Banyumas Regency, Baturaden District, Kemutuk Village, Baturaden Botanical Garden, $7.31248^{\circ} \mathrm{S}, 109.23578^{\circ} \mathrm{E}, 724 \mathrm{~m}$ a.s.1 MZB Amph 2711927120 (female); East Java: Semeru Mountain $8.00921^{\circ} \mathrm{S}, 112.26048^{\circ}$ E, $1332 \mathrm{~m}$ a.s.1. —MZB Amph 27121-27124 (male);

Microhyla gadjahmadai sp. nov. (Sumatra, Indonesia, $\mathrm{N}=23$; referred specimens not included in type series): Lampung: Tanggamus Regency, Tanggamus Mountain, above Gisting, $5.42306^{\circ} \mathrm{S}$, 104.69196 E E, 1117 m a.s.l.-UTA A-65746 (male); Tanggamus Regency, Semaka District, Sukaraja Village, Taman Nasional Bukit Barisan Selatan, 5.26545 ${ }^{\circ}$ S, $104.21573^{\circ}$ E-MZB Amph 3454 (male); Lampung Tengah Regency, Way Seputih District, $4.48307^{\circ} \mathrm{S}, 105.25599^{\circ} \mathrm{E}-\mathrm{MZB}$ Amph 15290 (male); Tanggamus Regency, Semaka District, Sedayu Village, 5.30401 S, $104.2899^{\circ} \mathrm{E}-$ MZB Amph 15292 (male); Tanggamus Regency, Hill top above Data Rajan, 5.35986 ${ }^{\circ} \mathrm{S}, 104.63287^{\circ}$ E, 1103 m a.s.1--MZB Amph 22387 (male); Tanggamus Regency, Ulubelu District, NE of town of Ngarip, 5.30636 S, $104.54826^{\circ}$ E, 877 m a.s.l.-MZB Amph 22388 (male); Tanggamus Regency, Ulubelu District, NE of town of Ngarip, $5.31567^{\circ} \mathrm{S}, 104.54343^{\circ} \mathrm{E}, 837 \mathrm{~m}$ a.s.1.-MZB Amph 22392

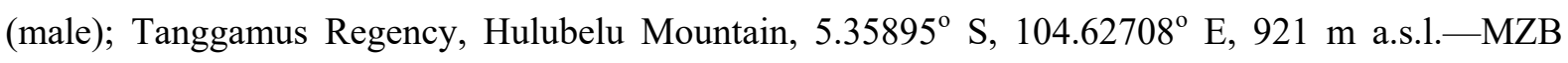
Amph 22394, 22400 (male); Tanggamus Regency, Tanggamus Mountain, above Gisting $5.42306^{\circ} \mathrm{S}$, 104.69196 ${ }^{\circ}$ E, 1117 m a.s.l-MMB Amph 22395, 22397, 22399 (male); Tanggamus Regency, Semaka District, Sedayu Village, 5.30401 S, 104.2899 E-MZB Amph 15291, 15293 (female); South Sumatera Province: Maura Enim Regency, Patah Mountain, near Segamit Village, $4.21989^{\circ} \mathrm{S}$, 103.471255 E, 1624 m a.s.1.-MZB Amph 26080 (male); Maura Enim Regency, Patah Mountain, near Segamit Village, $4.21715^{\circ} \mathrm{S}, 103.42165^{\circ}$ E, 1826 m a.s.l.-UTA A-65745 (female); Pagar Alam City, Dempo Mountain, 4.01386, 103.1876, m a.s.1 —MZB Amph 26079 (female). 